This item was submitted to Loughborough's Research Repository by the author.

Items in Figshare are protected by copyright, with all rights reserved, unless otherwise indicated.

\title{
Introduction: the politics of performance and the performance of politics
}

PLEASE CITE THE PUBLISHED VERSION

http://www.manchesteruniversitypress.co.uk/9780719091698/

\section{PUBLISHER}

Manchester University Press

VERSION

AM (Accepted Manuscript)

\section{PUBLISHER STATEMENT}

This work is made available according to the conditions of the Creative Commons Attribution-NonCommercialNoDerivatives 4.0 International (CC BY-NC-ND 4.0) licence. Full details of this licence are available at: https://creativecommons.org/licenses/by-nc-nd/4.0/

\section{LICENCE}

CC BY-NC-ND 4.0

\section{REPOSITORY RECORD}

Yeandle, Peter, and Katherine Newey. 2019. "Introduction: The Politics of Performance and the Performance of Politics". figshare. https://hdl.handle.net/2134/23833. 


\section{INTRODUCTION:}

\section{Politics, Performance and Popular Culture}

This book aims to create a space for historians and theatre scholars to continue a dialogue about the relationship between representations of politics in the theatre and the theatricality of politics itself in the long nineteenth century. Our aim is to provoke as much as to synthesise. The period of our investigation, from the time of the Napoleonic wars to the early twentieth century, resists synthesis. This is not a unified period, spanning the agitations and suppressions of democratic culture in Britain in the aftermath of the French Revolution, to the jingoism of late Victorian and Edwardian nationalism. By spreading across the boundaries of the Romantic and the Victorian, these essays examine a series of debates and conflicts in the development of industrial modernity, united by the manipulations and uses of performative strategies to engage with structures of political and cultural power. The terms in which we have staged the discussion -- 'performance,' 'politics,' 'history’ and 'theatre' -- are contingent. Our contributors engage with these key concepts in part to problematize them. If we can take it for granted that the problematization of key concepts is an important component in driving forwards debate, then we will succeed insomuch as the essays in this book represent the debate, and offer views with which to argue.

In drawing together scholars from political and social history, literary studies, and theatre history, we were immediately aware of the problem of the arbitrary identification of disciplinary divides. Political historians are joined by those who draw their methodologies from social history and cultural studies; theatre studies scholars by those working in English departments and those with research interests in textual analysis. The purpose of this book, then, is more than to demarcate relationships between politics and performance in the 
nineteenth century. As will be seen below plenty of studies have accomplished that task already. Rather, the original motive of our investigation - the exploration of ways that different scholars understand and use the analytical category of 'performance' - has morphed into a collection of theoretical position papers and case studies which tussle both with the relationship between politics and performance itself, and the nature of that relationship as an historiographical matter.

\section{The 'performative turn' in political history}

Recent years have witnessed a surge in the historiographical use of performance as an analytical category - what Peter Burke has called the 'performative turn'. ${ }^{1}$ Burke’s essay explains the development of the notion of performance (as an analytical category) from the dramaturgical model of social and political interaction of the 1940s and 50s. We have reached a point since the mid-1980s, Burke argues (he was writing in 2005), in which 'instead of drawing analogies between society and the theatre, the new approach dissolves the boundaries between them'. ${ }^{2}$ We now take for granted the need to analyse not only concrete historical occasions such as festivals, rituals and customs in their study of past politics but also to deconstruct abstract concepts - for example gender, class and identity - as performed categories. Burke’s observation on the historiographical dissolution of the boundaries between society and the theatre is important: the uptake of theatrical language in scholarship is borne out by a brief survey of recent research into nineteenth-century political history.

Boyd Hilton's catchy formulation is worth repeating: 'if the theatre was political, it is equally the case that politics was theatrical ... if public life was a stage, so too was the society it mirrored'. ${ }^{3}$ Hilton's argument - that the spectacular and unregulated nature of early nineteenth-century society was a reflection of the topsy-turvy world-turned-upside-down of 
Regency theatre, giving way to a mid-century age of moral, economic and political equipoise - is one that draws, in part, from the work of theatre scholars. Amongst others, Hilton cites the research of David Worrall and Jane Moody. ${ }^{4}$ For further evidence he might well have drawn from the seminal work of David Mayer that similarly argues for the confluence of politics and theatre. ${ }^{5}$ Likewise, a welter of research on the use of melodrama as a lens to think about Georgian politics substantiates the claim for a vital correlation of politics and the stage. ${ }^{6}$ Hilton's book - and argument - is an effective example of how scholars have drawn from interdisciplinary approaches; or, better put, exemplifies the adoption of the performative turn. $^{7}$

Examples abound. 'Political' histories have sought to recover nineteenth century politics as cultural formation. Recent biographical work has emphasised the importance of visual and performance culture: see, for instance, Richard Gaunt's revisionist research on Sir Robert Peel (and essay, Chapter 10 in this volume, that takes analysis further into political society as theatrical space). More recently, Jonathan Rose’s biography of Churchill establishes the crucial importance of the theatre on both his writing and the formation of his approach to political decision-making. ${ }^{8}$ John Belchem's and James Epstein thoughts on the cultural representation of the 'gentleman leader' invoke ideas of the individual's selfidentification as performer. ${ }^{9}$ Marcus Morris essay (Chapter 12), similarly, seeks to uncover the ways in which early leaders of the labour movement characterised themselves through costume and pitched their political performances according to their perception of audience. Indeed, the appropriation of the visual dynamics of nineteenth-century politics is evident in studies into the commodification of politicians. Henry Miller, for instance, has taken advances in the study of portrait culture and applied it to concepts of political literacy: his 
study seeks to investigate how the visual and the performative shaped public perceptions of politicians but how politicians, in turn, negotiated their relationships with political imagery. ${ }^{10}$ Janette Martin traces the use of elocution and gesture manuals in the training of public speaking - an acknowledgement that those addressing crowds were aware not only of the need to perform but to present themselves in visually arresting ways. ${ }^{11}$

If research has focused on how politicians conceptualised themselves as performers, and their constituents as audience, several studies have focused on the dynamics of performance space in which political debate took place. Several studies of the street, or town square, as performance space have problematized Habermasian notions of the public sphere, arguing - in general - for a contemporary awareness of everyday life as theatrical: thus street preaching, public hangings and promenades have all been historicised as dramatic sites. ${ }^{12}$ If Habermas' emphasis was upon the delineation of a bourgeois public, then recent work has emphasised not only how actors and audiences constructed themselves but the blurred differentials between the performed and the performed to. Work on the mass outdoors meetings of radicals, socialists and suffragists has emphasised the spectacular, visual and visceral dynamics of nineteenth-century politics: see, for instance, Mark Harrison’s research into the 'crowd' in history and Barbara Green's notion of the suffrage movement as both 'performative activism' and 'visibility politics'. ${ }^{13}$ Martin Hewitt’s important work on platform culture, similarly, attests to the importance of locating public speech as a relationship between orator and audience best understood in performative rather than textual terms. ${ }^{14}$ Jon Lawrence has shown how politicians - and electorate and those yet to be enfranchised - conceptualised the nineteenth-century hustings as a space presupposing both codes for would-be politicians as performers and audience as constituency. ${ }^{15}$ Frank 
Trentmann identifies how the doctrine of free trade, by the outset of the twentieth century, had reinvigorated face-to-face politics - not only by appeal to sites of popular culture (music hall, seaside resorts and shopping esplanades to name but a few locations) - but also as a result of the creation of a lively and interactive public debate. ${ }^{16}$ Rohan McWilliam and John Garrard have both examined Victorian concepts of citizenship and concluded that the prerequisite of citizenship was the conscious act of political participation - in other words, citizenship was to be performed. ${ }^{17}$ Scholars of political protest have been keen to incorporate notions of performance into their work: from Chartists to late-century socialist activists, the protest is well understood in the sense of a staged grievance, performing a collective claim for change to a preconceived audience. ${ }^{18}$ Charles Tilly's concept of 'contentious performances' has been particularly useful: Tilly identifies, through quantitative analysis, how social movements unite across nominal divisions in seeking to claim something justice, retribution, enfranchisement - through making communal and public 'claims' to a third party that draw from 'repertoires of dissent'. Who forms that third party, and how that claim is performed, is historically and class contingent. ${ }^{19}$ In this context, Janice Norwood's essay in this volume (Chapter 11), offers a performance analysis of the strike and the socialist march as forms of collective political expression. Mike Sanders' reassessment of Chartism in the light of the theatre (Chapter 2) moves from performance analysis of political actors to a wide-ranging assessment of the necessity of the theatrical and the performative in providing the framework for political action.

Performances could go indoors too. For Thomas Dixon, for instance, the Victorian courtroom was a dramatic arena offering theatrical context in which we might read more into Victorian histories of the emotions. ${ }^{20}$ Similar claims have been established for museums, memorials and the church. ${ }^{21}$ This list could go on, but three big questions are raised by this convergence of political history and the performative turn. First: from where did such 
developments originate? Second: what are the implications of these developments for theatre historians and performance studies scholars? Third, have historians and others borrowed the concept of performance with insufficient rigour and, in the identification of theatrical language and theatrical metaphor, neglected due attention to the full range of meanings inhered by 'performance' as an analytical category?

Part of the answer to the first question relates to the aftermath of the cultural turn. To frame an overly crude and simplistic dichotomy, until the eighties historians studying nineteenth century politics might well have positioned themselves as either 'traditional' or 'revisionist': the traditional would focus on constitutional, legislative, electoral and parliamentary history, the 'revisionist', drawing from Marxist determinism, would seek to understand politics as an expression of class relations and especially relationships of power between classes. The cultural turn, led in British scholarship by those previously at the vanguard of Marxism, challenged both approaches. ${ }^{22}$ As James Epstein outlines (In Practice), ${ }^{23}$ the influence of the cultural turn on political history has led - via the work of scholars such as Patrick Joyce, James Vernon, and Gareth Stedman Jones, and so on in the 1980s and ' 90 s - to the complicating and muddying of concepts of class. ${ }^{24}$ The turn to 'performance' reflects developments in cultural history that call for analysis of visual culture as well as the discursive treatment of documentary sources. Yet the performative turn, in the context of the new theatre historiography, enables to resurrection of class as an analytical category. If historians of class have struggled with the problematic demarcation of 'social history' and 'cultural history', then the uptake of performance enables the uptake of methodologies drawn from both. 


\section{II - Performance: a category for the analysis of political culture?}

The second and third questions can be addressed together. And it is to the development of 'performance' as academic praxis that we now turn. If, as Peter Burke argues, the performative turn is a development of the historical approach of 'society as theatre, ${ }^{25}$ then where better to start the investigation than with the history of the theatre? That is, with theatre history as history rather than as an addendum to the literary study of dramatic texts. Aye, there's the rub. This apparently straightforward question contains within it a number of complex historiographical matters. In this formulation, the theatre is a useful metaphor, rather than a model used for exploring the social practices of a culture. The framing of society 'as theatre,' 'theatrical' or performative, can too quickly move away from a serious consideration of the material practices of the theatre. Concepts of performance and the performative have generated significant new insights into social and political practices, and alerted us to the performances practices of the quotidian, rather than the virtuosic or 'extra-daily,' as performance anthropologists Eugenio Barba and Nicola Savarese call theatrical or aesthetic performance. ${ }^{26}$ However, such approaches tend to sweep over the complexities of recovering past performances, which are lost as soon as they are made, surviving by myriad traces which are often neither collected nor coherent. In writing about past theatrical performances, we can feel that we are writing into a void, entering a territory of unknowns. For social and political historians, trained in the use of documentation, material archives, and careful textual analysis, work on performance in the theatre requires an historical imagination which can perhaps be unsettling.

The difficulty is compounded when investigating the theatre of the nineteenth century. Up until the 1980s, the history of this busy and productive industry has been framed in almost entirely literary terms, or historicized through anecdote on the one hand, and fact-gathering 
antiquarianism with little analysis or theorization on the other. When considered as a branch of literature, the orthodox narrative of the theatre in the nineteenth century is that of the 'decline of the drama. ${ }^{27}$ The literary critical focus has been almost entirely on theatre as it survives through its dramatic literature, and the judgement has been that that literature was not worthy of study. Between Richard Brinsley Sheridan in the late eighteenth century, and George Bernard Shaw at the end of the nineteenth century, so the literary critical orthodoxy runs, dramatic literature was a wasteland. The theatre was dominated by star actors, and indulgent actor-managers; its playwrights produced what was regarded as literary ephemera drawn from the illegitimate culture of the early century: pantomime, melodrama, farce, burlesque, and comedietta. The few attempts at the 'legitimate' or high cultural drama of the poetic tragedy (the work of Robert Browning, or Alfred, Lord Tennyson, or Mary Russell Mitford), or the witty comedy of manners (such as plays by Sheridan Knowles or Catherine Gore) failed, undermined by overly large theatres, rowdy audiences, and commercial imperatives. The views of contemporary theatre practitioners, commentators and critics which throughout the nineteenth century emphasized the divisions between high and popular culture, and their judgements of aesthetic value, have been largely accepted by historians and critics in the twentieth century.

However, another narrative, counter to this story of decline and aesthetic failure has emerged in the last three decades. The 'new theatre history' aims to place British theatre in the long nineteenth century - that period from the aftermath of the French Revolution to the eve of the First World War -- as part of a much broader social and cultural move of the nation towards modernity. It is possible to place the theatre within accounts of industrialisation and urbanisation in Britain, and particularly in studies of the large urban centres of London, 
Manchester, Liverpool, and Leeds. Indeed, the theatre makes an excellent case study for industrial nation-making, in the debates and battles over its regulatory and economic structures. ${ }^{28}$ Theatre scholars have made clear connections between the idea of a National Theatre, and the idea of the nation; Loren Kruger opens her study of National theatres in Europe with the statement that

The idea of representing the nation in the theatre, of summoning a representative audience that will in turn recognize itself as nation on stage, offers a compelling if ambiguous image of national unity, less as an indisputable fact than as an object of speculation. ${ }^{29}$

Anselm Heinrich's discussion of Gladstone’s advocacy for the theatre as a national institution (Chapter 5) offers a specific case study of the interrelationship between theatrical politics and constructions of national identity. As noted above, theatre scholars have looked at the theatre as a somewhat rowdy part of the democratising process, particularly in the first half of the century. Such studies are alert to the serious ways in which theatre reflected and represented national political feeling, while some scholars make further claims for the influence of theatre policy and performances in the business of politics itself. ${ }^{30}$ Tracy C. Davis and Peter Holland go so far as to claim that 'nineteenth-century society itself performs.' 31 There is a longer argument here about the ways in which theatre offered a model for thinking through the idea of the nation; the theatre as a machine for thinking and imagining alternate possibilities for personal, social and national life could be powerfully transformative, as several chapters in this book explore. In order to achieve change, the argument goes, we need to be able to imagine that changed world, and theatre is one of the most immediate ways of representing such imagining. Here, the fundamental 'liveness' of theatre is crucial, as is its utilisation of 'presence,' and its affective power. Whatever else it may be, and however else it is framed or 
mediated, performance is an exchange of understandings and meanings within one physical space, in which actor and spectators are both engaged. In this respect, the theatre is not just an aesthetic object, but a social practice which appears to have considerable potential as a conduit for action and change.

Yet, for the most part, in social and political histories of Britain, the theatre has been relegated to marginal discussion as entertainment, or as a symptom of other social and political events and practices, rather than as a potential actor or agent in them. At the same time, as Peter Burke points out, concepts of the 'theatrical' and the 'performative' have become central in contemporary historiography. There is a point, however, as Burke cautions, when the concept of public action as 'performance' might be so loosely or broadly applied as to become meaningless. ${ }^{32}$ What do these terms mean, and how might they be made to do real analytical and intellectual work, in thinking about both the politics of performance in the nineteenth century, and the performance of politics? Rohan McWilliam has noted the way that such analyses have moved quickly from the consideration of the theatre itself, to that of the consequences of theatricality, and cautioned against the overuse of the term 'melodramatic. ${ }^{33}$ Yet the cultural impact of melodrama, particularly in the first half of the century, was significant: the first three chapters in this book (by Robert Poole, Mike Sanders, and Katherine Newey) explore instances of the impact of the generic characteristics, material and textual practices, and structures of feeling of melodrama on oppositional political movements, and investigate the mechanisms for exchange between the stage and the platforms of public debate.

We owe the turn to the performative to sociologist Erving Goffman, in his 
foundational The Presentation of Self in Everyday Life (1959) and linguist, J. L. Austin, who in How to Do Things with Words (1962), argued for certain forms of speech as performative. In speech-act theory, Austin argued that certain types of speech become action. Goffman and Austin offered different disciplinary approaches to a central observation of human behaviour can be seen (or 'framed' in Goffman's terms) as performance in both interpersonal and public exchanges. With this comes the recognition that the self -- the human subject -- may be framed or performed in different ways in different situations, and that the human subject is a constructed self, rather than a 'natural' or 'sentimental' self. And in those situations, the power of speech to do things can make things happen, thus opening the Habermasian public sphere to influences other than those of reason and Enlightenment rationality. As Eve Kosofsky Sedgwick and Andrew Parker remind us, Austin's 'performative utterances' have the potential to go wrong. ${ }^{34}$ The subject as citizen is not always rational, and may adjust his or her performance in public and political life to manufacture and influence public opinion; and public opinion may result in excess, or anti-rational affect.

The concept of 'performativity' has been taken up in many areas of social theory and cultural studies. The language is broadly theatrical, drawing also on older concepts of homo ludens, although Johan Huizinga’s foundational study Homo Ludens: a Study of the Play Element in Culture (1938) is rarely recalled in more recent discussions of play and performance as cultural or sociological phenomena. The idea that the human subject is constructed and performed in a series of social 'scripts' has been highly influential in theorizing the relationship of the individual to power, arguing that identity is produced by discursive means. In this model, self or subject status is produced by hegemonic structures and power relations, and behaviour is scripted, or performed. One of the most influential of 
these formulations is Judith Butler's use of the concept of the performative utterance as a foundation for her analysis of gender performativity, and her contention that 'identities are constructed iteratively through complex citational processes. ${ }^{35}$ Butler's work has given rise to what is perhaps the most controversial contemporary debate over the performative and the political to emerge in the early twenty-first century, and one which highlights dramatically (and sometimes violently) the potential for contradiction and paradox in deconstructivist notions of performativity and identity. Butler's use of performativity to challenge the feminist distinction between sex (biological female or male body) and gender (the social roles of femininity or masculinity) seeks to interrogate the oppressive nature of gendered identity. Instead, Butler argues, we should recognize that the body itself is a 'shaped by political forces with strategic interests in keeping that body bounded and constituted by the markers of sex $\cdot{ }^{36}$ But in an ironic reversal of concerns over the denial of individual agency in the concept of a social script, Butler's use of the social constructivist position of performativity in theorizing sexual and gender identity has been co-opted into broadly neo-liberal and individualist identity politics, particularly by some transgender and queer activists. Contemporary debates between these 'transactivists' and radical feminists over the apparent denial of '[biological] woman' as a category or class available to political analysis, throw into high relief possible consequences of performativity as a way of approaching the politics of identity and power, and remind us that deconstruction is not always aligned with some aspects of radical or oppositional politics. ${ }^{37}$

So, the idea of the performative, or as Burke puts it, the 'performative turn,' is clearly not without its debates and perils, particularly in seeing it as always a route to a progressive or liberationist politics. For theatre scholars in particular, the dangers of moving too far away 
from the material practices of the theatre mean that the terms may lose some of the cogency and power which makes them useful as tools of cultural analysis in the first place. If all is performative, that is scripted and rehearsed, then what is particular about what theatre can do in culture? Conversely, if all social behaviour can be analysed as performative, then how does that enable us to make distinctions between types of behaviour, and the situations in which action occurs? If reiterative social scripts produce identity, then how is such 'citation' to be regarded in relation to the valuation of liveness and presence in the performer-spectator exchange? Furthermore, while the performative model of social interaction is useful for understanding the reproduction of hegemony, it is open to critique for its closing off of the agency of individual actors in particular. The essays in this book, however, are part of a growing cross-disciplinary conversation in which historians of politics, political literature, and the theatre of the nineteenth century are engaged, in order to investigate the intricate workings of both the individual subject and class in relation to social structure and hegemonic power. These essays scope out common ground in method and material, using the theatre and performance, theatricality and the performative, as tools to analyse the specific places and conditions where the individual and the group meet, and where individual agency and social power work in exchange - be that an exchange characterised by resistance, complicity, or a combination of responses.

\section{III - Popular culture and public opinion}

In 1883, Blanchard Jerrold - playwright, journalist, and son of radical playwright and one of the original writers for Punch, Douglas Jerrold - ruminated on the question of what shaped ‘public opinion’:

The manufacture of public opinion remained long in its infancy but it has made extra-ordinary strides of late years... Since public opinion 
has become the motive power by which ministries are sustained and overthrown; since legislation answers to it as the electric bell answers to the pressure of a button; it is important to mark how this dominant force may be created, influenced, or directed. ${ }^{38}$

The Victorians were by turns excited by, proud of, and anxious about the force of popular opinion in public life. The existence and expression of robust public opinion was valued as evidence of the progress of science, education, and thought - the modernity of Victorian civilisation -- as well as a clear demonstration of the superior nature of British liberty of thought and expression. Yet it was also considered dangerous. In Blanchard Jerrold's observation that popular opinion 'may be created, influenced, or directed' is the tacit understanding that popular opinion is malleable, and thus can be influenced or directed to malign, as well as benign ends. The theatricality of this 'manufacture' of popular opinion was recognized by Victorians themselves, with the negative connotations of artifice which that term implies.

While contemporary historiography has embraced the performative turn, concerns in the nineteenth century about the theatricality of public life were of a piece with the deep vein of anti-theatricality in western, Christian Europe which focused on the nature of mimesis in the theatre as a specific form of representation. Writing about anti-theatricality, Davis and Postlewait note the difficulties that arise from a form of art which focuses our attention on the uncomfortable idea that we perform our social behaviour, suggesting that 'theatre and life are inseparable. ${ }^{39}$ If feeling, character, and speech could be convincingly feigned by actors in the theatre, then how could authenticity of public or private character be assured? Karen 
Halttunen's study of the anxieties around social interaction in mid-century America hold true for Britain as well, when she argues that the construction of 'the skilled performance of middle-class gentility’ undercut the sentimental investment in authenticity and sincerity. Thus the 'quest for sincerity of form thus inevitably turned and destroyed itself, for when sincerity became a matter of style or fashion, sentimental typology was rendered meaningless. ${ }^{40}$

There is overwhelming evidence (including many examples discussed in this book) that public opinion, expressed in popular terms and forms, was the object of anxiety and control, particularly through attempts to control and influence popular opinion expressed by working people. Attempts at control and censorship abounded in relation to popular culture; in the theatre they were folded into the very legislative and regulatory structures of the industry. The survival of Charles II’s Royal Patent from 1660 until 1843, when the Theatres Regulation Act removed the monopoly of the Theatres Royal, indicates that, however much the Patent monopoly was 'honour'd in the breach’ in the minor theatres' staging of melodrama and even versions of Shakespeare, the symbolic status of the legitimate theatre was worth fighting for. The 1843 Act, while ‘throwing open’ the drama (rather as Dickens’ Mr Wopsle longed for the throwing open of the Church in Great Expectations) established the much more long-lasting State censorship of the dramatic text through the Lord Chamberlain's Office, and his deputy, the Examiner of Plays, which was only removed in 1968.

As several of the essays in this book demonstrate, there was considerable debate in the public sphere about divisions and distinctions between high or élite culture, and popular or mass culture. These essays interrogate the popular as radicalism but also turn the spotlight 
on populism itself, as Malcolm Chase demonstrates in Chapter 9, in an approach which complements Poole’s use of melodrama to explore political activism. From Sanders' (Chapter 2) and Norwood's (Chapter 11) studies of the use of the street and the common as a political theatre, to the theatre itself as a site of mass popular culture and the dissemination of political ideology, be that imperialism - (Pritchard and Yeandle in Chapter 7, and Richards in Chapter 8) - or topical referencing of the Irish question (Jill Sullivan’s essay in Chapter 6) to the study of theatre and politics as participating in a common politics of affect, as Katherine Newey explores in Chapter 3. Our contributors investigate popular performance genres -music hall ballet, melodrama, pantomime, and spectacle, and interrogate the vitality and legitimacy of all kinds of performance; we are not concerned with theatrical hierarchies, except in so far as they dramatize (or make theatrical) social hierarchies and the stresses and tensions of the power relations which maintain them, as Caroline Radcliffe explores in Chapter 4. The realignment of the hierarchies of cultural production (to use Pierre Bourdieu's term) in the nineteenth century is one of the dominant narratives of modernity in the period. A study of the theatre and its performative elements - both on and off stage -- offers considerable evidence for studies of popular opinion and its manufacture and influence in the nineteenth century. It is in the study of the mainstream nineteenth century theatre that aesthetic and disciplinary divisions between high and low, elite and popular culture are challenged, and boundaries blurred. The theatre was both one of the most important cultural institutions of the nation - felt to represent the nation in so many ways - but also an industry, increasingly founded on a model of speculative capitalism, but enmeshed within older oligarchic structures of regulation and custom. ${ }^{41}$ In the wake of Zygmunt Baumann's concept of the doubleness of 'liquid modernity' - its desire for order and its constant radical reordering of that order -- and the economic precarity of its practices, ${ }^{42}$ we might see the theatre of the nineteenth century as offering a case study at large for the transformation of the 
public sphere. While high cultural critics throughout the nineteenth and twentieth centuries engaged in a constant re-erection of the barriers protecting high culture against the manufacture and influence of popular opinion, the essays in this book deliberately work across such boundaries. Their study of the theatre and the theatrical, performance and the performative in public life, with a due scepticism towards hierarchies of aesthetic and social value-judgements, enables a wider range of reference and a fruitful cross-disciplinary exchange between history and culture.

${ }^{1}$ Peter Burke, 'Performing History: the importance of occasions', Rethinking History 9 (2005), pp. 35-52.

${ }^{2}$ Burke, 'Performing History', p. 41.

${ }^{3}$ B. Hilton, A Mad, Bad and Dangerous People? England 1783-1846 (Oxford: Oxford University Press, 2006), pp. 33 and 36.

${ }^{4}$ David Worrall, Radical Culture: Discourse, Resistance and Surveillance, 1790-1820 (New York, 1992); Jane Moody, Illegitimate Theatre in London, 1770-1840 (Cambridge: Cambridge University Press, 2000).

${ }^{5}$ David Mayer, Harlequin in his Element: The English Pantomime, 1806-1836 (Cambridge, Mass: Harvard University Press, 1969).

${ }^{6}$ See, for example, Elaine Hadley, Melodramatic Tactics: Theatricalized Dissent in the English Marketplace, 1800-1885 (Redwood City, CA: Stanford University Press, 1995); Anna Clark, 'The politics of seduction in English popular culture, 1748-1848', in Jean Radford (ed.), The Progress of Romance: the Politics of Popular Fiction (London, 1986); Rohan McWilliam, 'Melodrama and the Historians,' Radical History Review 78 (2000), and 
Katherine Newey, 'Reform on the London Stage,' in Arthur Burns and Joanna Innes, Rethinking the Age of Reform: Britain 1780-1850 (Cambridge: Cambridge University Press, 2003). Robert Poole surveys the literature in his chapter in this volume.

${ }^{7}$ The same could be said for a number of other studies. Marc Baer's Theatre and Disorder in late Georgian England (Oxford: Oxford University Press, 1992), for instance, seeks explicitly to expose the blurred boundaries of theatrical and political cultures. So, too, does Julia Swindells in Glorious Causes: the grand theatre of political change, 1789-1832 (Oxford: Oxford University Press, 2001).

${ }^{8}$ Jonathan Rose, The Literary Churchill: Author, Reader, Actor (New Haven, CO: Yale University Press, 2014).

${ }^{9}$ Richard Gaunt, Sir Robert Peel: the life and legacy (London: I.B. Tauris, 2010). See also Gaunt's chapter in this collection. John Belchem and James Epstein, 'The nineteenth-century gentleman leader revisited’, Social History 22:2 (1997), pp. 174-93.

${ }^{10}$ Henry Miller, Politics Personified: Portraiture, Caricature and Visual Culture in Britain, 1830-1880 (forthcoming, Manchester U.P., 2015).

${ }^{11}$ J. Martin, 'Oratory, Itinerant Lecturing and Victorian Popular Politics: a case study of James Acland’ (1799-1876), Historical Research 86: 231 (2012), pp. 30-52.

${ }^{12}$ Christina Parolin, Radical Spaces: venues of popular politics in London, c. 1790-1845 (Canberra: Australia National University Press, 2010); Della Pocock (ed.), Exceptional Spaces: essays in performance and history (University of North Carolina Press, 1998). For case studies, see Matthias Reiss, 'Marching on the Capital: National Protest Marches of the British Unemployed in the 1920s and 1930s', in Matthias Reiss (ed.), The Street as Stage: Protest Marches and Public Rallies since the Nineteenth-Century (Oxford: Oxford University Press, 2007); and Steve Poole, ““Till Our Liberties be Secure”: popular sovereignty and public space in Bristol, 1780-1850’, Urban History 26:1 (1999), 40-54. 
${ }^{13}$ Mark Harrison, The Crowd and History: Mass Phenomena in English Towns, 1790-1835 (Cambridge: Cambridge University Press, 2002); Barbara Green, 'From Visible Flaneuse to Spectacular Suffragette: The Prison, the Street, and Sites of Suffrage', Discourse 17:2 (19945), pp. 67-97.

${ }^{14}$ Martin Hewitt, ‘Aspects of Platform Culture in Nineteenth-Century Britain’, NineteenthCentury Prose 29:1 (2002), pp. 1-32.

${ }^{15}$ Jon Lawrence, Electing our Masters: the Hustings in British Politics from Hogarth to Blair (Oxford: Oxford University Press, 2009).

${ }^{16}$ Frank Trentmann, Free Trade Nation: Commerce, Consumption and Civil Society in modern Britain (Oxford: Oxford University Press, 2008)

${ }^{17}$ John Garrard, Democratisation in Britain: Elites, Civil Society and Reform since 1800 (New York: Palgrave, 2002); Rohan McWilliam, ‘The Performance of Citizenship’, in Martin Hewitt (ed.), The Victorian World (London: Routledge, 2012), pp. 362-80.

${ }^{18}$ John Belchem, 'Radical Language, Meaning and Identity in the Age of the Chartists', Journal of Victorian Culture 10:1 (2005), pp. 1-14. Michael Sanders, The Poetry of Chartism: aesthetics, politics, history (Cambridge: Cambridge U.P., 2012); Peter Yeandle, 'Campaigning Histories', in Pedro Ramos Pinto and Bertrand Taithe (eds), The Impact of History: histories in the twenty-first century (London: Routledge, forthcoming); Baz Kershaw, 'Fighting in the Streets: Dramaturgies of Popular Protest', New Theatre Quarterly 13: 51 (1997), 255-76; Katrina Navickas, ‘Protest History or the History of Protest?’ History Workshop Journal 73:1 (2012), pp. 302-27.

${ }^{19}$ Charles Tilly, Contentious Performances (Cambridge: Cambridge University Press, 2008).

${ }^{20}$ Thomas Dixon, 'The Tears of Mr Justice Willes', Journal of Victorian Culture 17:1 (2012), pp. 1-23. 
${ }^{21}$ See, for instance, the introduction in Elin Diamond (ed.), Performance and Cultural Politics (London: Routledge, 2013); Joshua Edelman, Claire Chamber and Simon du Toit (eds), Performing Religion in Public (Basingstoke: Palgrave, 2013); John Shelton Reed, ““Ritualism Rampant in East London”: Anglo-Catholicism and the Urban Poor', Victorian Studies 31:3 (1988), pp. 375-403.

${ }^{22}$ Geoff Eley, 'Is all the World a text? From social history to the history of society two decades later' ', in Gabrielle Spiegel (ed.), New Direction in Historical Writing after the Linguistic Turn (London: Routledge, 2005), pp. 35-61. Geoff Eley and Keith Nield, The Future of Class in History: What's left of the social? (University of Michigan Press, 2007).

${ }^{23}$ James Epstein, In Practice: studies in the language and culture of popular politics in modern Britain (Stanford: Stanford U.P, 2003).

${ }^{24}$ James Vernon, Politics and the People: a study in English political culture, c. 1815-1867 (1993); Patrick Joyce, Visions of the People: Industrial England and the question of class, c. 1848-1914 (1993) - chapter 13 of which, 'Stages of Class: popular theatre and geographies of knowledge', is particularly important for this book; see also his The Rule of Freedom: Liberalism and the modern city (London: Verso, 2003); Gareth Stedman Jones, Languages of Class: studies in English working-class history (1983).

${ }^{25}$ Burke, 'Performing History’, p. 35.

${ }^{26}$ They define extra-daily technique as 'techniques which do not respect the habitual condiionings of the body.' Eugenio Barba and Nicola Savarese, A Dictionary of Theatre Anthropology: the Secret Art of the Performer (London: Routledge, 1991), p. 9.

${ }^{27}$ For an overview of this historiography, see Chapter 2 of Jacky Bratton, New Readings in Theatre History (Cambridge: Cambridge University Press, 2003).

${ }^{28}$ See Tracy C. Davis, The Economics of the British Stage, 1800-1914 (Cambridge: Cambridge University Press, 2000) esp. Ch. 1; Newey, ‘The 1832 Select Committee,’ and 
Jim Davis, 'Looking Towards 1843 and the End of the Monopoly,' in David Francis Taylor and Julia Swindells (eds) The Oxford Handbook of the Georgian Theatre, 1737-1832 (Oxford: Oxford University Press, 2014).

${ }^{29}$ Loren Kruger, The National Stage: Theatre and Cultural Legitimation in England, France, and America (Chicago: Chicago University Press, 1992), p. 1; see also Chapter 3 “”Our National House”: Patronizing the English National Theatre.’.

${ }^{30}$ For example, David Francis Taylor, Theatres of Opposition: Empire, Revolution, and Richard Brinsley Sheridan (Oxford: Oxford University Press, 2012).

${ }^{31}$ Tracy C. Davis and Peter Holland, 'Introduction: the Performing Society,' in Davis and Holland (eds), The Performing Century: Nineteenth-Century Theatre's History (Basingstoke: Palgrave Macmillan, 2007), p. 7.

${ }^{32}$ Burke, p. 43.

${ }^{33}$ McWilliam, 'Melodrama and the Historians,' and Katherine Newey, 'Victorian Theatricality,' in Hewitt (ed), The Victorian World, pp. 569-84.

34 'Introduction: Performativity and Performance,' in Andrew Parker and Eve Kosofsky Sedgwick (eds), Performativity and Performance ( London \& New York: Routledge, 1995), p. 3.

${ }^{35}$ Parker and Sedgwick, 'Introduction,’ p. 2.

${ }^{36}$ Butler, Gender Trouble: Feminism and the Subversion of Identity (London \& New York: Routledge, Rev. edn), p. 164.

37 The debate over 'woman' as a category also has an historiographical life, in an intense scrutiny of the concept of 'experience' by Joan Scott, 'The Evidence of Experience,' Critical Inquiry, Vol. 17, No. 4 (Summer, 1991), pp. 773-797. A good summary of the refutation of 
Scott's argument can be found in Laura Lee Downs, 'If "Woman” is Just an Empty Category, Then Why Am I Afraid to Walk Alone at Night? Identity Politics Meets the Postmodern Subject,' Comparative Studies in Society and History, Vol. 35, No. 2 (Apr., 1993), pp. 414437.

${ }^{38}$ Blanchard Jerrold, 'On the Manufacture of Public Opinion', The Nineteenth Century: A Monthly Review 13 (January-June, 1883), p.1081

${ }^{39}$ Tracy C. Davis and Thomas Postlewait (eds), ‘Theatricality: an Introduction,’ in Theatricality (Cambridge: Cambridge University Press, 2003), p. 11.

${ }^{40}$ Karen Halttunen, Confidence Men and Painted Women: a Study of Middle-Class Culture in America, 1830-1870 (New Haven: Yale University Press, 1982), p. 189.

${ }^{41}$ Tracy C. Davis offers a spectacular account of the ways in which the 'theatre as an entertainment industry [...] struggled in a continuum of laissez-faire and government interventions.' The Economics of the British Stage, 1800-1914 (Cambridge: Cambridge University Press, 2000), p. 7.

42 'Was not modernity a process of “liquefaction” from the start?' Zygmunt Bauman, Liquid Modernity (Cambridge: Polity Press, 2000; rev ed. 2012), p. 2. 